\title{
EFEKTIFITAS PENDEKATAN PEMBELAJARAN KONTEKSTUAL DAN PEMECAHAN MASALAH DITINJAU DARI KONSEP DIRI SISWA PADA PELAJARAN MATEMATIKA KELAS VIII SMP NEGERI DI KABUPATEN SRAGEN TAHUN PELAJARAN 2011/2012
}

\author{
Abdul Aziz KH, Mardiyana, Triyanto \\ Program Studi Pendidikan Matematika, \\ Program Pascasarjana Universitas Sebelas Maret Surakarta
}

\begin{abstract}
Abstrak
Penelitian ini bertujuan untuk mengetahui: (1). Manakah yang memberikan prestasi belajar matematika siswa yang lebih baik, pendekatan pembelajaran Kontekstual, Pemecahan Masalah atau Pembelajaran Langsung. (2). Manakah yang memberikan prestasi belajar matematika siswa yang lebih baik, siswa dengan konsep diri tinggi, sedang atau rendah. (3). Apakah pada masingmasing konsep diri siswa (tinggi, sedang dan rendah) pendekatan pembelajaran Kontekstual lebih baik dibanding Pemecahan Masalah dan Pembelajaran Langsung, dan Pemecahan Masalah lebih baik dibanding Pembelajaran Langsung. (4). Apakah pada masing-masing pendekatan pembelajaran (Kontekstual, Pemecahan Masalah dan Pembelajaran Langsung) pada siswa dengan konsep diri tinggi lebih baik dibanding dengan konsep diri sedang dan rendah serta apakah siswa dengan konsep diri sedang lebih baik dibanding dengan konsep diri rendah.

Penelitian ini merupakan penelitian eksperimen semu dengan desain faktorial 3x3. Populasi dari penelitian ini adalah siswa kelas VIII SMP Negeri di Kabupaten Sragen semester genap tahun pelajaran 2011/2012. Pengambilan sampel dilakukan dengan cara stratified cluster random sampling dengan sampel penelitian adalah siswa-siswi SMP Negeri 2 Sragen, SMP Negeri 1 Karangmalang, dan SMP Negeri 2 Karangmalang masing-masing terdiri dari tiga kelas, satu kelas sebagai kelas Pembelajaran Kontekstual, satu kelas sebagai kelas Pembelajaran Pemecahan Masalah dan satu kelas sebagai kelas Pembelajaran Langsung. Banyak anggota sampel seluruhnya adalah 265 siswa. Uji instrumen yang digunakan adalah uji validitas, reliabelitas, daya beda dan tingkat kesukaran. Uji normalitas menggunakan Lilliefors, uji homogenitas dengan uji Bartlett dan uji keseimbangan menggunakan uji-F. Uji hipotesis menggunakan uji anava dua jalan dengan sel tak sama.

Berdasarkan hasil pengujian hipotesis dalam penelitian ini dapat disimpulkan. (1). Pendekatan pembelajaran kontekstual memberikan prestasi belajar lebih baik daripada pembelajaran pemecahan masalah dan pembelajaran langsung, dan pembelajaran pemecahan masalah memberikan prestasi belajar lebih baik daripada pembelajaran langsung. (2). Siswa yang memiliki konsep diri tinggi mempunyai prestasi belajar lebih baik daripada siswa yang memiliki konsep diri sedang dan rendah, dan siswa dengan konsep diri sedang memberikan prestasi belajar lebih baik daripada siswa dengan konsep diri rendah. (3a). Pada siswa dengan konsep diri tinggi, pembelajaran pemecahan masalah memberikan prestasi belajar lebih baik daripada pembelajaran langsung. Sedangkan pendekatan pembelajaran kontekstual sama baiknya dengan pembelajaran pemecahan masalah dan pembelajaran langsung. (3b). Pada siswa dengan konsep diri sedang, pembelajaran kontekstual memberikan prestasi belajar lebih baik daripada pembelajaran langsung. Sedangkan pendekatan pembelajaran pemecahan masalah sama baiknya dengan pembelajaran kontekstual dan pembelajaran langsung. (3c). Pada siswa dengan konsep diri rendah, pendekatan pembelajaran kontekstual memberikan prestasi belajar lebih baik daripada pembelajaran pemecahan masalah. Sedangkan pendekatan pembelajaran pemecahan masalah dan kontekstual sama baiknya dengan pembelajaran langsung. (4a). Pada pendekatan pembelajaran kontekstual, semua siswa dengan beragam konsep diri memiliki prestasi belajar yang sama. (4b). Pada pendekatan pembelajaran pemecahan masalah, siswa dengan konsep diri tinggi memiliki prestasi belajar lebih baik daripada siswa dengan konsep diri sedang dan siswa dengan konsep diri tinggi memiliki prestasi belajar lebih baik daripada konsep diri rendah, dan siswa dengan konsep diri sedang akan lebih baik daripada siswa dengan konsep
\end{abstract}


diri rendah. (4c). Pada pendekatan pembelajaran langsung, semua siswa dengan beragam konsep diri memiliki prestasi yang sama.

Kata kunci : Pendekatan Pembelajaran Matematika, Kontekstual, Pemecahan Masalah, Pembelajaran Langsung, Prestasi Belajar, Konsep Diri.

\section{PENDAHULUAN}

Keberadaan manusia yang ada di dunia ini menuntut adanya pemenuhan kebutuhan hidup, dalam pemenuhannya tentu bergantung pada kualitas SDM yang dimiliki. Menurut Badan Pusat Statisktik penduduk Indonesia berjumlah 237.556.363 jiwa pada bulan Mei 2010. Secara kuantitas, jumlah penduduk Indonesia termasuk 10 besar, tetapi kualitasnya masih rendah. Sehingga masalah kualitas juga perlu diperhatikan untuk menjaga eksistensinya.

Salah satu yang penting untuk meningkatkan kualitas penduduk adalah pendidikan. Berdasarkan data PISA (Programme for International Student Assessment) tahun 2009 dari 65 negara peserta, Indonesia berada dibawah median, yaitu seperti Tabel 1.

Dari data tersebut, terlihat bahwa matematika menempati posisi paling bawah jika dibanding dengan reading dan science. Bangsa Indonesia melalui Kementerian Pendidikan dan Kebudayaan telah berupaya memperbaiki sektor pendidikan. Hal itu dapat dilihat dari perubahan kebijakan dan sistem pendidikan di Indonesia.

Perubahan yang dapat dilihat adalah sistem evaluasi pendidikan, yang sekarang menjadi UN (Ujian Nasional). Dengan materi ujinya adalah Bahasa Indonesia, Bahasa Inggris, Matematika dan IPA (Ilmu
Pengetahuan Alam). Hasil UN tahun pelajaran 2010/2011 di Kabupaten Sragen yaitu seperti Tabel 2.

Dari data tersebut, matematika masih menjadi mata pelajaran yang nilainya paling rendah. Sebuah keprihatinan, karena matematika secara keilmuan merupakan induknya ilmu dan teknologi, secara mata pelajaran matematika sebagai muaranya. Sehingga dibutuhkan perlakuan dan tindakan untuk memperbaikinya. Seluruh stake holder pendidikan di Indonesia berupaya memperbaiki pembelajaran matematika. Perbaikan tersebut mulai dari pendekatan pembelajaran, kreatifitas siswa, kompetensi guru, model pembelajaran, alat peraga sampai pada pemanfaatan teknologi.

Pendekatan pembelajaran memiliki peranan penting dalam proses belajar mengajar. Ada beberapa macam pendekatan pembelajaran, pendekatan pembelajaran yang berpusat pada guru banyak yang menyebabkan siswa cenderung bersifat pasif di kelas. Hal ini akan berakibat timbulnya kejenuhan pada diri siswa sehingga hasil yang diharapkan kurang maksimal. Sedangkan,pendekatan pembelajaran yang berpusat pada siswa, seperti kontekstual,pemecahan masalah, cycle learning, PMRI, inkuiri, reciprocal learning dan lain-lain. 
Tabel 1.1. Peringkat PISA

\begin{tabular}{|l|l|l|l|}
\hline \multicolumn{1}{|c|}{ No } & \multicolumn{1}{c|}{ Kategori } & \multicolumn{1}{c|}{ Peringkat } & \multicolumn{1}{c|}{ Keterangan } \\
\hline 1. & Reading & 57 & 10 negara terbawah \\
\hline 2. & Mathematics & 61 & 10 negara terbawah \\
\hline 3. & Science & 60 & 10 negara terbawah \\
\hline
\end{tabular}

(Sumber : http://www.pisa.oecd.org)

Tabel 1.2. Nilai rata-rata Ujian Nasional Kabupaten Sragen

\begin{tabular}{|l|l|l|}
\hline No & Mata Pelajaran & Nilai Rata-rata \\
\hline 1. & Bahasa Indonesia & 7,15 \\
\hline 2. & Bahasa Inggris & 7,14 \\
\hline 3. & Matematika & 6,96 \\
\hline 4. & IPA & 7,67 \\
\hline Rata-rata & 7,23 \\
\hline
\end{tabular}

(Sumber : Unit Pelaksana Teknis Pendidikan Kab. Sragen Tahun 2011)

Berdasarkan beberapa pendekatan pembelajaran tersebut, penelitian ini akan menggunakan pendekatan pembelajaran kontekstualdanpemecahan masalah. Pendekatan pembelajaran kontekstual adalah pembelajaran yang mampu membuat semua siswa memperkuat, mengembangkan, dan menerapkan pengetahuan dan keterampilan akademik mereka diberbagai kondisi, baik di dalam maupun di luar sekolah untuk menyelesaikan masalah-masalah nyata maupun simulasi. Pembelajaran kontektual terjadi ketika para siswa menerapkan dan mengalami hal-hal yang dialami dengan merujuk pada permasalahan-permasalahan nyata yang berhubungan dengan peran dan tanggung jawab mereka sebagai anggota keluarga, warga negara, siswa dan sebagai pekerja. kontekstual menekankan pemikiran yang lebih tinggi, alih pengetahuan antar mata pelajaran akademis, serta menghubungkan, menganalisis, dan menyusun informasi dan data dari berbagai sumber dan sudut pandang (Johnson, 2002: 309).
Sedangkan pendekatan pembelajaran pemecahan masalah yaitu pembelajaran yang harus diarahkan bagaimana menemukan penyebab utama dari suatu masalah, juga bagaimana caranya memecahkan suatu materi ke dalam bagianbagian yang lebih kecil. Dengan meminta siswa membuat suatu penulisan ilmiah mengenai suatu topik tertentu akan membuat siswa mengembangkan kemampuan ini. Selain itu siswa akan belajar bagaimana merangkum atau menggabungkan berbagai bagian informasi untuk membentuk suatu tulisan yang enak untuk dibaca. Mengajarkan siswa melihat sesuatu dengan cara berbeda, akan membuat siswa belajar fleksibel dalam memandang suatu permasalahan. Contohnya membuat pertanyaan matematika dalam bentuk soal cerita (Sutantoputri, 2004: 100).

Selain pendekatan pembelajaran, faktor lain yang mempengaruhi keberhasilan proses pembelajaran adalah siswa sendiri. Pada diri siswa terdapat beberapa karakteristik yang dapat mempengaruhi kegiatan belajar siswa antara lain: latar belakang pengetahuan, taraf 
pengetahuan, gaya belajar, konsep diri siswa (self esteem), dan lain-lain.

Penelitian ini akan menggunakan tinjauan psikologis dari konsep diri (selfesteem) yang dimiliki siswa. Menurut Stuard dan Sundeen (1998) konsep diri adalah penilaian individu terhadap hasil yang dicapai dengan menganalisa seberapa jauh perilaku memenuhi ideal dirinya. Dapat diartikan bahwa konsep diri menggambarkan sejauhmana individu tersebut menilai dirinya sebagai orang yang memiliki kemampuan, tanggung jawab, keberartian, berharga, dan kompeten. Konsep diri siswa ini memiliki sifat-sifat yang mirip dengan karakter, sehingga pemerintah melalui Dinas Pendidikan menekankan pentingnya pembentukan karakter untuk kemajuan pendidikan.

Pada pembelajaran kontekstual dan pemecahan masalah sering menggunakan keaktifan siswa, yaitu pada tugas individu maupun diskusi kelompok. Sehingga konsep diri siswa sangat dibutuhkan. Terutama pada pembelajaran pemecahan masalah,dinamisasi dalam pembelajaran berjalan cukup tinggi sehingga hanya siswa yang memiliki konsep diri tinggi yang mampu mengikuti pembelajaran tersebut.

Materi yang akan dijadikan sebagai instrumen penelitian adalah lingkaran, dengan memandang bahwa bentuk-bentuk lingkaran banyak digunakan dalam kehidupan sehari-hari, sehingga penggunaan bahan ajar dan alat peraga dapat diperoleh dengan mudah oleh guru maupun peserta didik, tepat digunakan pada pendekatan pembelajaran kontekstual. Materi lingkaran juga memiliki berbagai ragam persoalan yang dapat dikembangkan, sehingga mampu memberikan tantangan masalah kepada siswa, baik masalah individu maupun kelompok. Dengan demikian memilih pendekatan pemecahan masalah akan tepat digunakan dalam penelitian ini.

Materi lingkaran pada SKL UN (Standar Kompetensi Lulusan Ujian Nasional) tahun pelajaran 2010/2011 memilki 6 butir soal dari 40 butir soal yang diujikan, yang disajikan dalam tabel 3 .

Dari data tersebut dapat dilihat bahwa rata-rata daya serap kurang dari 70 yaitu 62,10 dan masih berada dibawah daya serap nasional. Sehingga dengan penelitian ini, diharapkan mampu meningkatkan daya serap materi lingkaran dengan menggunakan pendekatan pembelajaran kontekstual dan pemecahan masalah.

Berdasarkan uraian di atas, maka penelitian ini bertujuan untuk:

1. Mengetahui prestasi belajar yang lebih baik dari masing-masing pendekatan pembelajaran.

2. Mengetahui prestasi belajar yang lebih baik dari masing-masing konsep diri siswa.

3. Mengetahui prestasi belajar yang lebih baik pada pendekatan pembelajaran dari masing-masing konsep diri siswa.

4. Mengetahui prestasi belajar yang lebih baik pada konsep diri dari masingmasing pendekatan pembelajaran. 


\section{PEMBAHASAN}

Kontekstual atau disebut secara lengkap dengan Sistem Kontekstual adalah sebuah proses pendidikan yang bertujuan menolong para siswa melihat makna didalam materi akademik yang mereka pelajari dengan cara menghubungkan subjek-subjek akademik dengan konteks dalam kehidupan keseharian mereka, yaitu dengan konteks keadaan pribadi, sosial, dan budaya mereka (Johnson, 2002: 309). Kontekstual dikembangkan oleh The Washington State Concortium for Contexstual, yang melibatkan 11 perguruan tinggi, 20 sekolah dan lembaga-lembaga yang bergerak dalam dunai pendidikan di Amerika Serikat. Pendekatan kontekstual merupakan konsep belajar yang membantu guru mengaitkan antara materi yang diajarkan dengan situasi dunia nyata siswa dan mendorong siswa membuat hubungan antara pengetahuan yang dimilikinya dengan penerapannya dalam kehidupan mereka sebagai anggota keluarga dan masyarakat (US Departement of Education, 2001).

Menurut Yamin (2005: 74) menyatakan bahwa pemecahan masalah juga dikenal braims torming, merupakan pembelajaran yang merangsang pikiran dan menggunakan wawasan tanpa melihat kualitas pendapat yang disampaikan siswa, guru memotivasi siswa untuk mengeluarkan pendapat mereka dan menghargainya sekalipun pendapat siswa tersebut salah menurut guru, pembelajaran

ini

Tabel 3. Daya Serap Materi Lingkaran Pada UN 2010/2011

\begin{tabular}{|l|l|l|}
\hline \multicolumn{1}{|c|}{ Indikator } & Kab & Nas \\
\hline 1.Menghitung luas juring pada lingkaran dari unsur yang diketahui & 79,37 & 78,14 \\
\hline 2.Menghitung besar sudut pusat atau sudut keliling pada lingkaran & 58,90 & 65,44 \\
\hline 3.Menentukan volume bangun ruang sisi datar dan sisi lengkung & 64,58 & 62,77 \\
\hline 4.Menentukan volume bangun ruang sisi datar dan sisi lengkung & 75,87 & 85,00 \\
\hline 5.Menentukan luas bangun ruang sisi datar dan sisi lengkung & 34,58 & 38,93 \\
\hline 6.Menentukan luas bangun ruang sisi datar dan sisi lengkung & 59,32 & 66,27 \\
\hline Rerata & 62,10 & 66,09 \\
\hline
\end{tabular}

(Sumber : Data Pamer Depdiknas Tahun 2011)

dapat dilaksanakan apabila siswa telah berada pada tingkat yang lebih tinggi dengan prestasi yang tinggi pula. Menurut Ediger (2009) "Problem solving is a vital skill for all to develop. Developmentally and at increasing levels of difficulty, pupils must be able to solve personal mathematics problems". Yaitu pemecahan masalah adalah suatu keterampilan yang penting untuk berkembang. Saat perkembangan dan meningkatnya kesulitan, siswa harus mampu memecahkan masalah matematika secara pribadi. Pembelajaran dengan pemecahan masalah dipandang sebagai pembelajaran yang meningkatkan kemampuan siswa dalam berpikir tingkat tinggi. Karena siswa setiap hari selalu dihadapkan pada suatu masalah.

Pembelajaran langsung yaitu suatu pembelajaran yang dilakukan guru kepada murid secara langsung, cara penyampaian yang utama dilakukan melalui ceramah dan 
dapat dikembangkan melalui tulisan di

pembelajaran langsung, pendekatan

papan tulis atau alat peraga untuk kontekstual, dan berbasis pemecahan memperjelas informasi.Hakekat pembelajaran langsung adalah guru menyampaikan ilmu pengetahuan kepada siswa, sehingga pembelajaran terpusat pada guru. Siswa dipandang sebagai obyek yang menerima apa saja yang diberikan oleh guru. Pembelajaran langsung dasampaikan dalam beberapa metode, tetapi yang dominan adalah metode ceramah, sehingga pembelajaran langsung yang dimaksud dalam penelitian ini didefinisikan sebagai metode ceramah. Menurut Yamin (2005: 35) metode ceramah berbentuk penjelasan konsep, prinsip dan fakta, pada akhirnya pembelajaran ditutup dengan tanya jawab antara guru dan siswa. Sehingga ceramah adalah sebuah bentuk interaksi melalui penerangan dan penuturan lisan dari guru masalah dapati dilihat pada Tabel 4 .

Penelitian ini dilaksanakan pada bulan Desember 2011 sampai dengan bulan Agustus 2012. Sampel yang terpilih untuk pengambilan data yaitu SMPN 2 Sragen, SMPN 1 Karangmalang dan SMPN 2 Karangmalang. Setelah dilakukan uji prasyarat yang meliputi uji keseimbangan, uji normalitas dan uji homogenitas dilakukan analisis varian (ANAVA), yaitu suatu desain penelitian yang digunakan untuk meneliti pengaruh dari perlakuan pendekatan pembelajaran yang berbeda dari tiga kelompok yang dihubungkan dengan konsep diri siswa terhadap prestasi belajar matematika. Desain faktorial yang digunakan 3x3, dengan kesimpulan berdasarkan hasil pada Tabel 5.

kepada siswa. Perbedaan antara

Tabel 4 Perbedaan Pembelajaran

\begin{tabular}{|l|l|l|}
\hline Kontekstual & Pemecahan masalah & Pembelajaran Langsung \\
\hline $\begin{array}{l}\text { Peranan guru tidak dominan } \\
\text { hanya sebagai fasilitator }\end{array}$ & $\begin{array}{l}\text { Peranan guru tidak dominan } \\
\text { hanya sebagai fasilitator }\end{array}$ & Peran guru sangat dominan \\
\hline $\begin{array}{l}\text { Pembelajaran dimulai dengan } \\
\text { materi yang kontekstual dari } \\
\text { guru atau dari siswa }\end{array}$ & $\begin{array}{l}\text { Pembelajaran dimulai dengan } \\
\text { mengajukan permasalahan dari } \\
\text { guru atau siswa }\end{array}$ & $\begin{array}{l}\text { Pembelajaran } \\
\text { dengan menerangkan materi } \\
\text { oleh guru dan permasalahan } \\
\text { diberikan setelah materi } \\
\text { disampaikan }\end{array}$ \\
\hline $\begin{array}{l}\text { Siswa lebih aktif berperan } \\
\text { dalam pembelajaran }\end{array}$ & $\begin{array}{l}\text { Siswa lebih aktif berperan } \\
\text { dalam pembelajaran }\end{array}$ & $\begin{array}{l}\text { Siswa kurang aktif dalam } \\
\text { pembelajaran an an an }\end{array}$ \\
\hline $\begin{array}{l}\text { Materi pada awal pembelajaran } \\
\text { berupa masalah realistik }\end{array}$ & $\begin{array}{l}\text { Materi pada awal pembelajaran } \\
\text { tidak harus berupa masalah } \\
\text { realistik }\end{array}$ & $\begin{array}{l}\text { Materi } \\
\text { pembelajaran berupa fakta, } \\
\text { definisi, konsep dan prinsip }\end{array}$ \\
\hline $\begin{array}{l}\text { Dalam pembelajaran timbul } \\
\text { interaksi dua arah }\end{array}$ & $\begin{array}{l}\text { Dalam pembelajaran timbul } \\
\text { interaksi dua arah }\end{array}$ & $\begin{array}{l}\text { Kurang terjadi interaksi dua } \\
\text { arah }\end{array}$ \\
\hline $\begin{array}{l}\text { Menggunakan matematisasi } \\
\text { horizontal dan vertikal }\end{array}$ & $\begin{array}{l}\text { Menggunakan matematisasi } \\
\text { horizontal dan vertikal }\end{array}$ & $\begin{array}{l}\text { Menggunakan rumus yang } \\
\text { sudah diajarkan guru }\end{array}$ \\
\hline $\begin{array}{l}\text { Lebih banyak waktu untuk } \\
\text { KBM }\end{array}$ & $\begin{array}{l}\text { Lebih banyak waktu untuk } \\
\text { KBM }\end{array}$ & $\begin{array}{l}\text { Tidak banyak memerlukan } \\
\text { waktu untuk KBM }\end{array}$ \\
\hline
\end{tabular}


Tabel 5. Rangkuman Analisis Variansi

\begin{tabular}{|l|l|l|l|}
\hline Sumber & JK & dk & RK \\
\hline $\begin{array}{l}\text { Pendk } \\
\text { Pemb. (A) }\end{array}$ & 11756,23 & 2 & 5878 \\
\hline Konsep Diri (B) & 11986,2043 & 2 & 5993 \\
\hline Interaksi (AB) & 14374,7867 & 4 & 3593 \\
\hline Galat & 96129,3558 & 256 & 375 \\
\hline Total & 134246,5769 & 264 & \\
\hline
\end{tabular}

Berdasarkan Tabel 5 tampak bahwa:

a. Pada efek utama A (pendekatan pembelajaran), harga statistik uji $\mathrm{F}_{\mathrm{a}}=15,6539$ dan $\mathrm{F}_{0,05 ; 2 ; 256}=$ 3,0311, ternyata $F_{a}>F_{0,05 ; 2 ; 256}$ dengan demikian $\mathrm{H}_{0 \mathrm{~A}}$ ditolak, berarti menerima $\mathrm{H}_{1 \mathrm{~A}}$ yaitu paling tidak ada satu $\alpha_{i}$ yang tidak nol. Sehingga pada tingkat signifikansi $\alpha=0,05$ terdapat perbedaan efek penggunaan pendekatan pembelajaran terhadap prestasi belajar siswa. Dengan kata lain penggunaan pendekatan pembelajaran kontekstual, pemecahan masalah dan pembelajaran langsung berpengaruh terhadap prestasi belajar matematika siswa kelas VIII semester 2 pada pokok bahasan lingkaran.

b. Pada efek utama B (konsep diri siswa), harga statistik uji $\mathrm{F}_{\mathrm{b}}=$ 15,9601 dan $\mathrm{F}_{0,05 ; 2 ; 256}=3,0311$ ternyata $\mathrm{F}_{\mathrm{b}}>\mathrm{F}_{0,05 ; 2 ; 256}$ dengan demikian $\mathrm{H}_{0 \mathrm{~B}}$ ditolak, berarti menerima $\mathrm{H}_{1 \mathrm{~B}}$ yaitu paling tidak ada satu $\beta_{\mathrm{j}}$ yang tidak nol. Sehingga pada tingkat signifikansi $\quad \alpha=0,05 \quad$ terdapat

\begin{tabular}{|l|l|l|l|}
\hline RK & F obs & $\mathrm{F}_{\alpha}$ & Keputusan \\
\hline 578,115 & 15,6539 & 3,0311 & $\mathrm{H}_{0 \mathrm{~A}}$ Ditolak \\
\hline 5993,1022 & 15,9601 & 3,0311 & $\mathrm{H}_{0 \mathrm{~B}}$ Ditolak \\
\hline 375,5053 & 9,5703 & 2,4069 & $\mathrm{H}_{0 \mathrm{AB}}$ Ditolak \\
\hline
\end{tabular}

perbedaan efek konsep diri terhadap prestasi belajar siswa. Dengan kata lain tingkat konsep diri tinggi, sedang dan rendah berpengaruh terhadap prestasi belajar matematika siswa kelas VIII semester 2 pada pokok bahasan lingkaran.

c. Pada efek interaksi AB (pendekatan pembelajaran dan konsep diri siswa), harga statistik uji $\mathrm{F}_{\mathrm{ab}}=9,5703$ dan $\mathrm{F}_{0,05 ; 4 ; 256}=$ 2,4069 , ternyata $\mathrm{F}_{\mathrm{ab}}>\mathrm{F}_{0,05 ; 4 ; 256}$ dengan demikian $\mathrm{H}_{0 \mathrm{AB}}$ ditolak, berarti menerima $\mathrm{H}_{1 \mathrm{AB}}$ yaitu paling tidak ada satu $(\alpha \beta)_{\mathrm{ij}}$ yang tidak nol. Hal ini berarti pada tingkat signifikan $\quad \alpha=0,05$ terdapat interaksi antara pendekatan pembelajaran dan tingkat konsep diri siswa terhadap prestasi belajar matematika siswa kelas VIII semester 2 pada pokok bahasan lingkaran.

Setelah dicari dengan rumus-rumus Scheffe', berdasarkan hasil perhitungan uji komparasi ganda antar baris (lihat Tabel 6) diperoleh: 
1) $\mu_{1 .} \neq \mu_{2 .}\left(H_{0}\right.$ ditolak). Ini berarti pendekatan pembelajaran kontekstual memberikan efek yang tidak sama dengan pendekatan pembelajaran pemecahan masalah, dengan melihat rerata marginal $\left(\bar{x}_{1}=\right.$ 74,0267 dan $\bar{x}_{2 .}=65,617$ ) siswa yang diberikan pendekatan pembelajaran kontekstual mempunyai prestasi lebih baik daripada siswa yang diberikan pendekatan pembelajaran pemecahan masalah.

2) $\mu_{1 .} \neq \mu_{3 .}\left(\mathrm{H}_{0}\right.$ ditolak). Ini berarti pendekatan pembelajaran kontekstual memberikan efek yang tidak sama dengan pendekatan pembelajaran langsung, dengan melihat rerata $\left(\bar{x}_{1 .}=74,0267\right.$ dan $\bar{x}_{3 .}=$ $57,4583)$ siswa yang diberikan pendekatan pembelajaran kontekstual mempunyai prestasi lebih baik daripada siswa yang diberikan pendekatan pembelajaran langsung.

3) $\mu_{2 .} \neq \mu_{3}$. $\left(H_{0}\right.$ ditolak). Ini berarti pendekatan pembelajaran pemecahan masalah memberikan efek yang tidak sama dengan pendekatan pembelajaran langsung, dengan melihat rerata $\left(\bar{x}_{2 .}=65,617\right.$ dan $\left.\bar{x}_{3 .}=57,4583\right) \quad$ siswa yang diberikan pendekatan pembelajaran pemecahan masalah mempunyai prestasi lebih baik daripada siswa yang diberikan pendekatan pembelajaran langsung.

Tabel 6. Rangkuman Komparasi Ganda Antar Baris

\begin{tabular}{|l|l|l|l|l|l|l|}
\hline Ho & $(\mathbf{X . i}-\mathbf{X . j})^{\mathbf{2}}$ & $\frac{\mathbf{1}}{\boldsymbol{n}_{\boldsymbol{i} .}}+\frac{\mathbf{1}}{\boldsymbol{n}_{\boldsymbol{j}}}$ & RKG & $\mathbf{F}_{\text {obs }}$ & $\mathbf{F}_{\text {Tabel }}$ & Keputusan \\
\hline$\mu_{1 .}=\mu_{2 .}$ & 70,7221 & 0,0240 & 375,5053 & 7,8474 & 6,0621 & Ditolak \\
\hline$\mu_{1 .}=\mu_{3 .}$ & 274,5097 & 0,0238 & 375,5053 & 30,7160 & 6,0621 & Ditolak \\
\hline$\mu_{2 .}=\mu_{3 .}$ & 66,5642 & 0,0211 & 375,5053 & 8,4012 & 6,0621 & Ditolak \\
\hline
\end{tabular}

Keterangan:

$\mu_{1 .}:$ rerata prestasi belajar matematika untuk pendekatan pembelajaran kontekstual

$\mu_{2}$ : rerata prestasi belajar matematika untuk pendekatan pembelajaran pemecahan masalah

$\mu_{3 .}:$ rerata prestasi belajar matematika untuk pendekatan pembelajaran langsung

Tabel 7. Rangkuman Komparasi Ganda Antar Kolom

\begin{tabular}{|l|l|l|l|}
\hline $\mathrm{H}_{0}$ & $F_{\text {obs }}$ & $F_{\text {kritik }}$ & Kesimpulan \\
\hline$\mu_{\cdot 1}=\mu_{\cdot 2}$ & 6,9861 & 6,0621 & $\mathrm{H}_{0}$ ditolak \\
\hline$\mu_{\cdot 1}=\mu_{\cdot 3}$ & 34,7951 & 6,0621 & $\mathrm{H}_{0}$ ditolak \\
\hline$\mu_{\cdot 2}=\mu_{\cdot 3}$ & 11,6553 & 6,0621 & $\mathrm{H}_{0}$ ditolak \\
\hline
\end{tabular}

Keterangan:

$\mu_{.1}$ : rerata prestasi belajar matematika untuk konsep diri tinggi

$\mu_{2}$ : rerata prestasi belajar matematika untuk konsep diri sedang

4) $\mu_{.3}$ : rerata prestasi belajar matematika untuk konsep diri rendah 
Setelah dicari dengan rumus-rumus Scheffe', berdasarkan hasil perhitungan uji komparasi ganda antar kolom diperoleh:621\}

1) $\mu_{.1} \neq \mu_{.2}\left(\mathrm{H}_{0}\right.$ ditolak). Ini berarti ada perbedaan terhadap prestasi belajar jika dilihat dari konsep diri siswa. Dari Tabel rerata marginal dapat disimpulkan bahwa siswa yang mempunyai konsep diri tinggi mempunyai prestasi belajar lebih baik jika dibandingkan dengan siswa yang mempunyai konsep diri sedang, hal ini ditunjukkan dengan besarnya $F_{.1 \cdot 2}=$ $6,9861>6,0621=F_{\text {kritik }}$.

2) $\mu_{.1} \neq \mu_{.3}\left(\mathrm{H}_{0}\right.$ ditolak). Ini berarti ada perbedaan terhadap prestasi belajar jika dilihat dari konsep diri siswa. Dari Tabel rerata marginal dapat disimpulkan bahwa siswa yang mempunyai konsep diri tinggi mempunyai prestasi belajar lebih baik jika dibandingkan dengan siswa yang mempunyai konsep diri rendah, hal ini ditunjukkan dengan besarnya $F_{.1-3}=$ $34,7951>6,0621=F_{\text {kritik }}$.

3) $\mu_{\cdot 2} \neq \mu_{\cdot 3}\left(\mathrm{H}_{0}\right.$ ditolak $)$. Ini berarti ada perbedaan terhadap prestasi belajar jika dilihat dari konsep diri siswa. Dari Tabel rerata marginal dapat disimpulkan bahwa siswa yang mempunyai konsep diri sedang mempunyai prestasi belajar lebih baik jika dibandingkan dengan siswa yang mempunyai konsep diri rendah, hal ini ditunjukkan dengan besarnya $F_{.2-3}=$ $11,6553>6,0621=F_{\text {kriti }}$.

Tabel 8. Rangkuman Uji Lanjut Antar Sel Pada Kolom Sama

\begin{tabular}{|l|l|l|l|l|l|}
\hline $\mathrm{H}_{0}$ & $\mathrm{~F}$ obs & F kritik & \multicolumn{1}{l|}{ DK } & Keputusan \\
\hline$\mu_{\cdot 11}=\mu_{\cdot 21}$ & 6,0316 & 15,7974 & $\{\mathrm{~F}$ & $\mathrm{F}>15,7974\}$ & Diterima \\
\hline$\mu_{\cdot 21}=\mu_{\cdot 31}$ & 27,2677 & 15,7974 & $\{\mathrm{~F}$ & $\mathrm{F}>15,7974\}$ & Ditolak \\
\hline$\mu_{11}=\mu \cdot 31$ & 6,0935 & 15,7974 & $\{\mathrm{~F}$ & $\mathrm{F}>15,7974\}$ & Diterima \\
\hline$\mu_{\cdot 12}=\mu_{.22}$ & 4,0673 & 15,7974 & $\{\mathrm{~F}$ & $\mathrm{F}>15,7974\}$ & Diterima \\
\hline$\mu_{\cdot 22}=\mu_{\cdot 32}$ & 4,8626 & 15,7974 & $\{\mathrm{~F}$ & $\mathrm{F}>15,7974\}$ & Diterima \\
\hline$\mu \cdot 12=\mu \cdot 32$ & 18,9123 & 15,7974 & $\{\mathrm{~F}$ & $\mathrm{F}>15,7974\}$ & Ditolak \\
\hline$\mu_{\cdot 13}=\mu_{\cdot 23}$ & 24,3347 & 15,7974 & $\{\mathrm{~F}$ & $\mathrm{F}>15,7974\}$ & Ditolak \\
\hline$\mu_{\cdot 23}=\mu \cdot 33$ & 4,7710 & 15,7974 & $\{\mathrm{~F}$ & $\mathrm{F}>15,7974\}$ & Diterima \\
\hline$\mu \cdot 13=\mu \cdot 33$ & 7,6990 & 15,7974 & $\{\mathrm{~F}$ & $\mathrm{F}>15,7974\}$ & Diterima \\
\hline
\end{tabular}

Berdasarkan hasil perhitungan yang pemecahan masalah memberikan disajikan pada Tabel 8 dengan taraf prestasi belajar yang sama. signifikansi 0,05 untuk uji antar sel pada kolom yang sama dapat ditarik kesimpulan

a. Pada konsep diri tinggi:

Keputusan uji $\mu_{11}=\mu_{21}$ diterima, hal ini menunjukkan bahwa pembelajaran kontekstual dan
Keputusan uji $\mu_{21}=\mu_{31}$ ditolak, dengan melihat reratanya diperoleh $\bar{x}_{21}=86,533>60,2667=\bar{x}_{31}$ hal ini menunjukkan pemecahan masalah memberikan prestasi belajar lebih baik daripada pembelajaran langsung. 
Keputusan uji $\mu_{11}=\mu_{31}$ diterima, hal ini menunjukkan bahwa pembelajaran kontekstual memberikan prestasi belajar yang sama dengan pembelajaran langsung.

b. Pada konsep diri sedang:

Keputusan uji $\mu_{12}=\mu_{22}$ diterima, hal ini menunjukkan bahwa pembelajaran kontekstual memberikan prestasi belajar yang sama dengan pemecahan masalah.

Keputusan uji $\mu_{22}=\mu_{32}$ diterima, hal ini menunjukkan bahwa pemecahan masalah memberikan prestasi belajar sama dengan pembelajaran langsung.

Keputusan uji $\mu_{12}=\mu_{32}$ ditolak, dengan melihat reratanya diperoleh $\bar{x}_{12}=78,00>65,81=\bar{x}_{32}$ hal ini menunjukkan bahwa pembelajaran kontekstual memberikan prestasi belajar lebih baik daripada pembelajaran langsung.

c. Pada konsep diri rendah:

Keputusan uji $\mu_{13}=\mu_{23}$ ditolak, dengan melihat reratanya diperoleh $\bar{x}_{13}=70,4>65,617=\bar{x}_{23}$ hal ini menunjukkan bahwa pembelajaran kontekstual memberikan prestasi belajar lebih baik daripada pemecahan masalah.

Keputusan uji $\mu_{23}=\mu_{33}$ diterima, hal ini menunjukkan bahwa pembelajaran pemecahan masalah memberikan prestasi belajar sama dengan pembelajaran langsung.

Keputusan uji $\mu_{13}=\mu_{33}$ diterima, hal ini menunjukkan bahwa pembelajaran kontekstual memberikan prestasi belajar yang sama dengan pembelajaran langsung.

\section{Rangkuman Uji Lanjut Antar Sel Pada Baris Sama}

\begin{tabular}{|c|c|c|c|c|c|}
\hline $\mathrm{H}_{0}$ & F obs & F kritik & \multicolumn{2}{|c|}{ DK } & Keputusan \\
\hline$\mu_{.11}=\mu_{.21}$ & 0,6733 & 15,7974 & $\{\mathrm{~F}$ & $\mathrm{F}>15,7974\}$ & diterima \\
\hline$\mu_{.21}=\mu_{.31}$ & 1,9595 & 15,7974 & $\{F$ & $\mathrm{F}>15,7974\}$ & diterima \\
\hline$\mu_{11}=\mu_{.31}$ & 0,3132 & 15,7974 & $\{\mathrm{~F}$ & $\mathrm{F}>15,7974\}$ & diterima \\
\hline$\mu_{.12}=\mu_{.22}$ & 16,1343 & 15,7974 & $\{\mathrm{~F}$ & $\mathrm{F}>15,7974\}$ & ditolak \\
\hline$\mu_{.22}=\mu_{.32}$ & 20,3892 & 15,7974 & $\{\mathrm{~F}$ & $\mathrm{F}>15,7974\}$ & ditolak \\
\hline$\mu .12=\mu .32$ & 71,5410 & 15,7974 & $\{\mathrm{~F}$ & $\mathrm{F}>15,7974\}$ & ditolak \\
\hline$\mu_{.13}=\mu_{.23}$ & 0,6941 & 15,7974 & $\{\mathrm{~F}$ & $\mathrm{F}>15,7974\}$ & diterima \\
\hline$\mu_{.23}=\mu_{.33}$ & 0,0217 & 15,7974 & $\{F$ & $\mathrm{F}>15,7974\}$ & diterima \\
\hline$\mu .13=\mu .33$ & 0,8588 & 15,7974 & $\{\mathrm{~F}$ & $\mathrm{F}>15,7974\}$ & diterima \\
\hline
\end{tabular}

Kesimpulan dari hasil perhitungan uji antar sel pada baris yang sama tersebut yaitu:

1) Pada pembelajaran kontekstual:
Keputusan uji $\mu_{11}=\mu_{12}, \mu_{12}=\mu_{13}$ dan $\mu_{11}=\mu_{13}$ diterima, hal ini menunjukkan bahwa konsep diri tinggi, sedang dan rendah 
memberikan prestasi belajar yang sama.

2) Pada pembelajaran pemecahan masalah:

Keputusan uji $\mu_{21}=\mu_{22}$ ditolak, dengan melihat reratanya diperoleh $\bar{x}_{21}=86,533>66,75=\bar{x}_{22}$ hal ini menunjukkan bahwa konsep diri tinggi memberikan prestasi belajar lebih baik daripada konsep diri sedang.

Keputusan uji $\mu_{22}=\mu_{23}$ ditolak, dengan melihat reratanya diperoleh $\bar{x}_{22}=66,75>56,4324=\bar{x}_{23}$ hal ini menunjukkan konsep diri sedang memberikan prestasi belajar lebih baik daripada konsep diri rendah.

Keputusan uji $\mu_{21}=\mu_{23}$ ditolak, dengan melihat reratanya diperoleh $\bar{x}_{21}=86,533>44,875=\bar{x}_{23}$ hal ini menunjukkan bahwa konsep diri tinggi memberikan prestasi belajar lebih baik daripada konsep diri rendah.

3) Pada pembelajaran langsung:

Keputusan uji $\mu_{31}=\mu_{32}, \mu_{32}=\mu_{33}$ dan $\mu_{31}=\mu_{33}$ diterima, hal ini menunjukkan bahwa konsep diri tinggi, sedang maupun rendah memberikan prestasi belajar yang sama.

\section{KESIMPULAN}

Berdasarkan hasil analisis data dapat diperoleh kesimpulan sebagai berikut:
1. Pendekatan pembelajaran kontekstual memberikan prestasi belajar lebih baik daripada pembelajaran pemecahan masalah dan pembelajaran langsung, dan pembelajaran pemecahan masalah memberikan prestasi belajar lebih baik daripada pembelajaran langsung.

2. Siswa yang memiliki konsep diri tinggi mempunyai prestasi belajar lebih baik daripada siswa yang memiliki konsep diri sedang dan rendah, dan siswa dengan konsep diri sedang memberikan prestasi belajar lebih baik daripada siswa dengan konsep diri rendah.

3. a. Pada siswa dengan konsep diri tinggi, pembelajaran pemecahan masalah memberikan prestasi belajar lebih baik daripada pembelajaran langsung. Sedangkan pendekatan pembelajaran kontekstual sama baiknya dengan pembelajaran pemecahan masalah dan pembelajaran langsung.

b. Pada siswa dengan konsep diri sedang, pembelajaran kontekstual memberikan prestasi belajar lebih baik daripada pembelajaran langsung. Sedangkan pendekatan pembelajaran pemecahan masalah sama baiknya dengan pembelajaran kontekstual dan pembelajaran langsung.

c. Pada siswa dengan konsep diri rendah, pendekatan pembelajaran kontekstual memberikan prestasi belajar lebih baik daripada 
pembelajaran pemecahan masalah.

Sedangkan pendekatan pembelajaran pemecahan masalah dan kontekstual sama baiknya dengan pembelajaran langsung.

4. a. Pada pendekatan pembelajaran kontekstual, semua siswa dengan beragam konsep diri mempunyai prestasi belajar yang sama.

b. Pada pendekatan pembelajaran pemecahan masalah, siswa dengan konsep diri tinggi mempunyai prestasi belajar lebih baik daripada siswa dengan konsep diri sedang dan siswa dengan konsep diri tinggi memiliki prestasi belajar lebih baik daripada konsep diri rendah. Sedangkan siswa dengan konsep diri sedang lebih baik daripada siswa dengan konsep diri rendah.

c. Pada pendekatan pembelajaran langsung, semua siswa dengan beragam konsep diri mempunyai prestasi yang sama.

\section{DAFTAR PUSTAKA}

Programme for International Student Assessment, diakses pada tanggal 6 Maret 2012 dari: http://www.pisa.oecd.org/pages/0,3417 ,en $32252351 \quad 32235731 \quad 1 \quad 1 \quad 1 \quad 1$ $1,00 . h t m l$

Yamin, Martinis. 2005. Strategi Pembelajaran Berbasis Kompetensi. Ciputat: Gaung Persada Pres.

Ediger, Marlow. (2009). Content and Pedagogy. College Student Journal ProQuest Education Journals Pg 714

Depdiknas. (2008) Modul PLPG Guru Matematika SMK, Surabaya: UNESA.

Johnson, Elaine B., 2002 Contextual Teaching and Learning. Corwin Press. California. Alih bahasa MLC Bandung

Stuart \& Sundeen (1998). Principle and Pratice of Psychiatric Nursing. 6th. Ed. Philadelphia: The C V Mosby.

Sutantoputri, Widiawati. 2004, Desember. "Pembelajaran Strategi Kognitif".Psikologi Univ Tarumanagara Jakarta.Yayasan Obor Indonesia. JURNALPROVITAE, volume

1. 